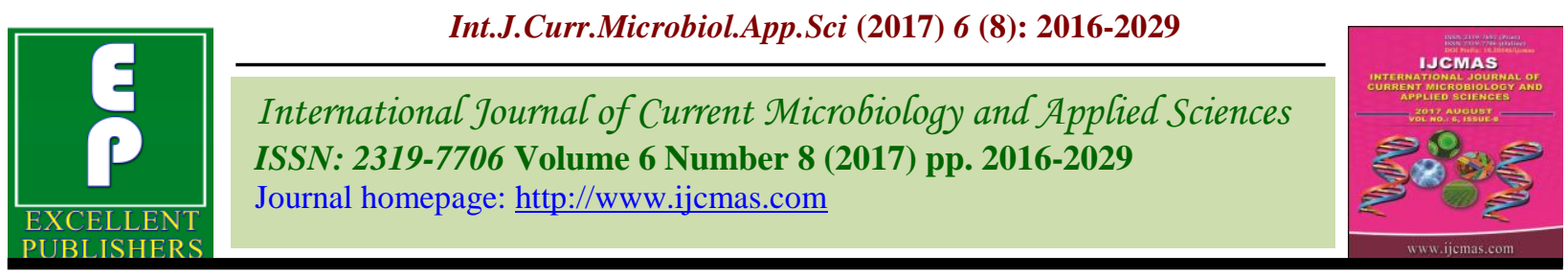

Original Research Article

https://doi.org/10.20546/ijcmas.2017.608.240

\title{
Impact of Aqueous/Ethanolic Goji Berry (Lycium barbarum) Fruit Extract Supplementation on Vitamin D Stability in Yoghurt
}

\author{
Vaibhav Kumar Maurya and Manjeet Aggarwal* \\ Department of Basic and Applied Science, National Institute of Food Technology \\ Entrepreneurship and Management, Kundli, Sonepat 131 028, Haryana, India \\ *Corresponding author
}

\begin{tabular}{|c|c|}
\hline & BSTRACT \\
\hline Keywords & \multirow{7}{*}{$\begin{array}{l}\text { Deficiency of vitamin D is a multifaceted phenomenon. On one hand, it depends } \\
\text { on sun exposure and consumption pattern while on the other hand, it depends } \\
\text { onit's stability in target food matrix. It is assumed that the supplementation of } \\
\text { bioactive phenolic compounds in target food matrix could result in higher stability } \\
\text { of vitamin D. The current study was intended to evaluate the feasibility of } \\
\text { supplementation of polyphenolic goji berry (Lycium barbarum) extract in yoghurt } \\
\text { and to study its impact on vitamin D stability in yoghurt during shelf life. For that } \\
\text { purpose yoghurt (fortified with vitamin D } 600 \mathrm{IU} / 100 \mathrm{ml} \text { ) was supplemented with } \\
0.05,0.10 \text { and } 0.15 \% \text { (W/V) with both aqueous as well ethanolic extract. We have } \\
\text { also evaluated consumer's acceptability of polyphenol extract supplemented } \\
\text { yoghurt during its shelf life. The result indicates that supplementation of yoghurt } \\
\text { with goji berry polyphenolic ethanolic extract }(0.1 \% \text { W/V) displayed greater } \\
\text { ability to inhibit vitamin D degradation without affecting the consumer palatability } \\
\text { during shelf life. }\end{array}$} \\
\hline & \\
\hline & \\
\hline Supplementation, & \\
\hline $\begin{array}{l}\text { Vitamin D, } \\
\text { Polyphenolic } \\
\text { extract. }\end{array}$ & \\
\hline Article Info & \\
\hline $\begin{array}{l}\text { Accepted: } \\
\text { 19 June } 2017 \\
\text { Available Online: } \\
10 \text { August } 2017\end{array}$ & \\
\hline
\end{tabular}

\section{Introduction}

Vitamin D refers to a group of secosteroid compounds, which are synthesized in plants and animals as the action of UV radiation. Vitamin D is susceptible to degradation and the extent depends on storage conditions such temperature, light and humidity, which is due to oxidation of the conjugate double bond (Grady and Thakker, 1980; LI and MIN, 1998). Vitamin D deficiency is prevailing even in countries with sufficient sunshine due to their socioeconomic constraints that prevent people to expose themselves to sunlight and to consume vitamin D rich food (Roy et al., 2015; Wayse et al., 2004). In that case, fortification of vitamin $\mathrm{D}$ in food becomes compulsion for healthy life. Fortification of vitamin D in food matrix also brings limitation within it, which is degradation of vitamin $\mathrm{D}$ in target food (Tangpricha et al., 2003; Wagner et al., 2008).

This creates need for supplementation of natural antioxidants within target food which offers antioxidant properties against the oxidation of vitamin D. Berry fruits like strawberry, blackberry, cranberry and goji berry are recognized for their diverse phenolic compounds which offer high antioxidative properties. Goji berry (Lycium barbarum)is 
one of the well reported berry rich in diverse groups of phytochemicals (Benchennouf et al., 2017; Chen et al., 2014; Vulić et al., 2016; Yang et al., 2015; Zhang, 2013; Zhang et al., 2016). Recent literature suggests that addition of natural fruits extract, rich in phenolic contents, offers high antioxidative properties as well as various other health benefits (Cossu et al., 2009; El-Said et al., 2014; Karaaslan et al., 2011). Due high antioxidant activity goji berry extract have been applied in variety of food products such as sausages (Bulambaeva et al., 2014), beverages (Ducruet et al., 2017; Navarro et al., 2011), dairy products (ROTAR et al., 2014; Rotar et al., 2015), bread (Yang, 2016) and chocolate (Morais Ferreira et al., 2017).

To date milk is considered as the most suitable candidate for vitamin $\mathrm{D}$ fortification. But it brings several challenges with it one of them is the generation of reactive oxygen species (ROS) due presence of riboflavin which one of primary source for ROS (LI and MIN, 1998). There is scarcity of data on vitamin $D$ fortification in foods other than milk. The stability of vitamin $\mathrm{D}$ has been reported in bread, processed dairy products (Wagner et al., 2008), juice (Tangpricha et al., 2003) and tea (Grant et al., 2017). These reports suggest that vitamin D stability depends on matrix, composition, processing and local environments $(\mathrm{pH}$, water activity and temperature of target food).Yoghurt is a fermented dairy product for lactose intolerant consumer. It is among the most common dairy products consumed across the globe, which also contains probiotic that makes it even healthier food. Yoghurt could be a potential vehicle for vitamin $\mathrm{D}$ delivery for various reasons: (i) the milk fat may offer high stability and bioavailability of vitamin D (ii) yoghurt is rich source of calcium and can consume by lactose intolerant consumers as it contains lactose in traces. Despite of various health benefits goji berry has been not exploited to supplement dairy product. There are very few studies present in current literature reporting supplementation of daily products with goji berry (ROTAR et al., 2014; Rotar et al., 2015). This brings immense opportunity to fortify yoghurt with polyphenolic aqueous as well ethanolic goji berry fruit extract. The present study was undertaken to evaluate the vitamin D stability in yoghurt supplemented with aqueous/ ethanolic polyphenolic goji berry extract during its shelf life.

\section{Materials and Methods}

\section{Raw materials}

Pasterurised toned milk (Motherdaiy, India), edible coconut oil and dried goji berry fruit (Lycium barbarum) were purchased from a local supermarket. Commercial yoghurt culture (yo-FAST-88) provided by Chr. Hansen, Hrsholm, Denmark.

\section{Chemicals and reagents}

HPLC grade chemicals (n-hexane, ethanol, and isopropyl alcohol), sodium chloride, Folin-Ciocalteu reagent, Dimethyl sulfoxide (DMSO) were procured from Merck chemicals Company, Germany. Vitamin $\mathrm{D}_{3}$ and gallic acid were purchased from Sigma chemicals. 1, 1-diphenyl-2-picrylhydrazyl (DPPH) and Tween 80 was procured from SRL chemicals. While soya lecithin (Leciva 70S) was purchased from Vav Life Sciences, India.

\section{Preparation of aqueous extract of goji} berry polyphenol

Preparation of the gojiberry polyphenol aqueous extract was carried out by Cossu et al., (2009) method with some modification (Cossu et al., 2009). $5 \mathrm{~g}$ of lyophilized (Benchtop, Vir Tis, USA) gojiberrry fruit was 
homogenized $20 \mathrm{ml}$ milli Q water using tissue homogenizer (Polytron, Kinematic AG, Switterzerland) and subjected to boiling for $30 \mathrm{~min}$ and centrifuged at $6000 \mathrm{~g}$ for $15 \mathrm{~min}$. The super natent was collected frozed and concentrated using lyophilizer (Benchtop, VirTis, USA). The concentrated phenol extract was stored at $-20^{\circ} \mathrm{C}$ untile further use.

\section{Preparation of ethanolic extract of goji} berry polyphenol

Extraction of ethanolic polyphenol was carried out using Donno et al., (2015)with some modification (Donno et al., 2015). $5 \mathrm{~g}$ of lyophilized gojiberrry fruit (Benchtop, VirTis, USA) was homogenized $200 \mathrm{ml}$ absolute ethanol and subjected to boiling for 30 min (Polytron, Kinematic AG, Switterzerland) and centrifuged at $6000 \mathrm{~g}$ for $15 \mathrm{~min}$.

The super natent was collected and concentrated using rotary evaporator at $55^{\circ} \mathrm{C}$ for $5 \mathrm{~min}$ (Buchi, Switterzerland). The concentrated phenol extract was stored at $20^{\circ} \mathrm{C}$ until further use.

\section{Vitamin D nanoemulsion premix}

Vitamin $\mathrm{D}_{3}$ emulsion was prepared with four basic components oil phase, containing coconut oil, soy bean lecithin (Leciva), vitamin $\mathrm{D}$ and Tween 80 , and aqueous phase containing mili $\mathrm{Q}$ water and $5 \% \mathrm{NaCl}$.

The emulsion was prepared according to Phase inversion temperature (PIT) process (Fathi and Varshosaz, 2013 Heurtault et al., 2003; Kiani et al., 2017). Preparation method includes two basic steps: (i) Formation of W/O emulsion by homogenizing all components (Coconut oil, Tween 80, Lecithin, $\mathrm{NaCl}$, vitamin $\mathrm{D}$ and water) at $15000 \mathrm{rpm}$ for $5 \mathrm{~min}$ (Polytron, Kinematic AG, Switzerland). Then solution was allowed to heat from room temperature to about $85^{\circ} \mathrm{C}$ (above the PIT) and followed by cooling it to $65^{\circ} \mathrm{C}$ (bellow the PIT) in shaker waterbath (Metrex Scientific Instruments, India). This resulted in formation of an $\mathrm{O} / \mathrm{W}$ emulsion. In order to cross the phase inversion zone (PIZ) 3 temperature cycles were carried out from $85^{\circ} \mathrm{C}$ to $65^{\circ} \mathrm{C}$. (ii) Sudden dilution with chilled water $\left(0^{\circ} \mathrm{C}\right)$ led to irreversible shock and breaking of the micro emulsion system and forming of stable nanoemulsion. Final vitamin $\mathrm{D}$ concentration in nanoemulsion premix was $100000 \mathrm{IU} / 2.50 \mathrm{mg} / \mathrm{mL}$

\section{Preparation of yoghurt}

$16 \mathrm{~g}$ sucrose was added in vitamin $\mathrm{D}$ fortified toned milk and then heated in a waterbath at $85^{\circ} \mathrm{C}$ for $30 \mathrm{~min}$, cooled to approximately $43^{\circ} \mathrm{C}$, inoculated with commercial yoghurt culture and transferred to $100 \mathrm{ml}$ cups, incubated at $43^{\circ} \mathrm{C}$ for $4 \mathrm{~h}$ in BOD incubator (Metrex Scientific instrument, India)and stored at $4^{0} \mathrm{C}$ overnight before further analysis.

\section{Yoghurt fortification}

To prepare fortified yoghurt with goji berry polyphenol extract and vitamin $\mathrm{D}$ premix, the coagulum was broken by gentle stirring using a hand blender and mixed with concentrated goji berry polyphenol aqueous/ethanolic extract $(0.05,0.10$ and $0.15 \% \mathrm{~W} / \mathrm{V})$ and vitamin D $500 \mathrm{IU} / 12.5 \mu \mathrm{g} / 100 \mathrm{~mL}$ as final concentration using vitamin $\mathrm{D}$ emulsion premix.

Resulting yoghurt samples were transferred to sterile plastic sample containers with air tight cap and stored at $4^{0} \mathrm{C}$ in refrigerator. Yoghurt fortified with vitamin $\mathrm{D}$ only was considered as control. Total 7 formulations were made which were as such 


\section{Sensory evaluation}

The sensory characteristics of yoghurt formulations fortified with goji berry polyphenolic aqueous/ethanolic extract as well as vitamin D were assessed for sensory characteristics by a panel of experienced 25 judges who were requested to record the score of liking or disliking quality parameters for color, flavor, body and texture on a 9-point hedonic scale and result was presented in terms of overall acceptability (TundeAkintunde and Souley, 2009).

\section{Total phenolic content estimation}

The total phenolic content of the yoghurt formulations supplemented with aqueous and ethanolic goji berry extract was determined by Folin-Ciocalteu method by measuring absorbance at $715 \mathrm{~nm}$ in double beam spectrophotometer (Shimadzu UV-2600, Japan) (Zhang et al., 2016).

\section{Reactive oxygen scavenging activity (RSA) estimation}

The RSA of the yoghurt formulations supplemented with aqueous and ethanolic gojiberry extract was determined by 1,1diphenyl-2-picrylhydrazyl (DPPH) method by measuring absorbance at $517 \mathrm{~nm}$ in double beam spectrophotometer (Shimadzu UV2600, Japan) (Yang et al., 2015).

\section{Extraction of vitamin D from yoghurt}

Vitamin D extraction was carried out using (Dimartino, 2007; Pastore et al., 1997) with some modification. $5 \mathrm{~g}$ of yoghurt sample containing vitamin $\mathrm{D}_{3}$ was taken in amber color bottle and $10 \mathrm{ml}$ of DMSO was pipetted. The mixture was incubated at $45^{\circ} \mathrm{C}$ in shaker water bath for $30 \mathrm{~min}$ (Metrex Scientific instrument, India). Mixture was allowed to cool down at room temperature. Further
$100 \mathrm{ml}$ of $\mathrm{n}$-hexane was added to bottle containing sample and mix thoroughly for 10 min on magnetic stir. Then mixture was allowed to stand for at least $10 \mathrm{~min}$ without agitation for phase separation. Then the supernatant was pipetted out and filtered with Whatman 1 paper through sodium sulphate to avoid the moisture. The filtrate was passed through a $0.45 \mu \mathrm{m}$ nylon syringe filter and collected into a suitable HPLC vial and chromatographed.

\section{Standard Preparation}

Crystalline vitamin $\mathrm{D}_{3}$ (cholecalciferol; 100 $\mathrm{mg}$ ) was weighed into a $100.0 \mathrm{~mL}$ volumetric flask and dissolved and diluted to volume with $\mathrm{n}$-hexane. This is the $40000 \mathrm{IU} / \mathrm{mL}$ stock solution. A $25.0 \mathrm{~mL}$ aliquot of stock solution was transferred using a pipet to a $50.0 \mathrm{~mL}$ volumetric flask and diluted to volume with $\mathrm{n}$-hexane. This is the $4000 \mathrm{IU} / \mathrm{mL}$ working standard solution. Calibration was performed by using different dilution from 40, 400, 800, 1200,1600 and $20000 \mathrm{IU} / \mathrm{mL}$.

\section{Instrument conditions}

Vitamin D was quantified using HPLC (UFLC, Shimadzu, Japan) equipped with auto injector using a silica column $250 \times 4.6 \mathrm{~nm}$ with particle size $5 \mu \mathrm{m}$ and pore size $10 \AA$. The liquid chromatograph was operated in isocratic mode with a flow rate of $1.0 \mathrm{~mL} / \mathrm{min}$ mobile phase $(90 \%$ n-hexane and $10 \%$ Isopropyl alcohol) and a wavelength of 254 $\mathrm{nm}$ by photodiode array detector (AOAC, 979.24). Column temperature was $25^{\circ} \mathrm{C}$ and a $10 \mu \mathrm{L}$ injection volume was used. The retention time for vitamin D3 detection was found to be $4.72 \mathrm{~min}$.

\section{Statistical analysis}

The data obtained in the present research was analyzed statistically using Graph prism pad 
6.1 for analysis of variance (ANOVA). $95 \%$ confident interval ( $\mathrm{p}<0.05)$ was set throughout the data analysis to identify significant differences. Dunnett's multiple comparison tests and Tuckey's multiple compression tests were used to test the significant difference between different yoghurt samples.

\section{Results and Discussion}

\section{pH of yoghurt supplemented with aqueous/ethanolic polyphenolic extract}

The $\mathrm{pH}$ values of the goji berry polyphenolic aqueous and ethanolic extract supplemented yoghurt, fortified with vitamin $\mathrm{D}_{3}$, was estimated on $1^{\text {st }}$ day, $10^{\text {th }}$ day and $20^{\text {th }}$ day of storage and results are presented in figure 3 . There was slight decrease in $\mathrm{pH}$ of all yoghurt formulations registered during their shelf life.

As result indicates on $1^{\text {st }}$ day all yoghurt formulations significantly varied from control sample (Y) but on $10^{\text {th }}$ day and $20^{\text {th }}$ day $\mathrm{pH}$ of all formulations were not significantly different from control ( $1^{\text {st }}$ day Y). Similar slight decrease in $\mathrm{pH}$ values was recorded in yoghurt when it was supplemented with grape and callus extract (Karaaslan et al., 2011).

\section{Total phenolic substance}

Total phenolic content was estimated in goji berry polyphenolic aqueous and ethanolic extract supplemented yoghurt. The results obtained from yoghurt samples were displayed in figure 1. Among the assayed yoghurt samples highest phenolic content was observed in $\mathrm{YE}_{3}(582.667 \pm 25 \mathrm{mg} \mathrm{GAE} / 100 \mathrm{~g})$ formulation while it was least in control $(50 \pm 5 \mathrm{mg} \mathrm{GAE} / 100 \mathrm{~g})$ formulation within $1^{\text {st }}$ day yoghurt formulations. It was also observed that total phenolic content of each formulation is significantly decreased during storage. Maximum loss in total phenolic content was recorded in $\mathrm{YA}_{3}$ formulation which varied from575 \pm 22 to $531 \pm 32 \mathrm{mg}$ $\mathrm{GAE} / 100 \mathrm{~g}$. While maximum retention of total phenolic content was noticed in $\mathrm{YE}_{3}$ formulation which was recorded from $582 \pm 25$ to $574 \pm 10 \mathrm{mg} \mathrm{GAE} / 100 \mathrm{~g}$.

\section{DPPH radical scavenging activity (RSA)}

The free radical scavenging activity of yoghurt samples was measured by DPPH RSA method and results were displayed in figure 3. The results revealed that as the concentration of polyphenolic extract increases the antioxidant activity enhanced significantly for both aqueous and ethanolic extract (Fig. 2). Results clearly indicate that yoghurt supplemented with ethanolic goji berry extract have greater antioxidant activity than that of yoghurt supplemented with aqueous goji berry fruit extract. Our results were supported by another study where yoghurt was supplemented with polyphenolic extract (Cossu et al., 2009; El-Said et al., 2014; Karaaslan et al., 2011) The least antioxidant activity was observed in control sample $(10.97 \pm 2.9 \%$ in Y formulation) while maximum antioxidant activity was observed in $\mathrm{YE}_{3}$ formulation $(64.40 \pm 1.2 \%)$. It was observed that free radical scavenging activity (RSA) decreases during the storage. The maximum decrease in RSA was $\mathrm{YA}_{1}(33.16$ \pm 2.5 to $8 \pm 2.1 \%$ form $1^{\text {st }}$ day to $20^{\text {th }}$ day respectively) yoghurt formulation while it was least decreased in $\mathrm{YE}_{3}$ formulation (64.46 \pm 1.1 to $53.68 \pm 1.81 \%$ form $1^{\text {st }}$ day to $20^{\text {th }}$ day respectively). The RSA in all formulations were significantly higher in goji berry extract supplemented yoghurt formulation but yoghurt supplemented with $0.15 \%(\mathrm{~W} / \mathrm{V}) \mathrm{had}$ maximum RSA values. The substantial quantity of TPC in yoghurt was well correlated with RSA. Similar kind of decrease in RSA during shelf life was registered when curd was fortified with strawberry polyphenolic extract (Singh et al., 2013). 
Fig.1 Total phenol content of yoghurt fortified with goji berry polyphenolic aqueous/ethanolic extract and vitamin D. Values are expressed in mean $\pm S D(n=3)(p \leq 0.05)$. a, b, c, d, e, and $f$ represent significant differences between $\mathrm{Y} \times \mathrm{YA}_{1}, \mathrm{Y} \times \mathrm{YA}_{2}, \mathrm{Y} \times \mathrm{YA}_{3}, \mathrm{Y} \times \mathrm{YE}_{1}, \mathrm{Y} \times \mathrm{YE}_{2}$, and $\mathrm{Y} \times \mathrm{YE}_{3}$ within the $1^{\text {st }}$ day, $10^{\text {th }}$ day and $20^{\text {th }}$ day yoghurt formulations where $\mathrm{Y}$ formulation is considered as control with each group $\left(1^{\text {st }}\right.$ day, $10^{\text {th }}$ day and $20^{\text {th }}$ day $)$. Further $\mathrm{a}^{*}, \mathrm{~b}^{*}$ and $\mathrm{c}^{*}$ represent significance difference between $1^{\text {st }}$ day x $10^{\text {th }}$ day, $1^{\text {st }}$ day $\times 20^{\text {th }}$ and $10^{\text {th }}$ day $\times 20^{\text {th }}$ day within individual samples $\left(\mathrm{Y}, \mathrm{YA}_{1}, \mathrm{YA}_{2}, \mathrm{YA}_{3}, \mathrm{YE}_{1}, \mathrm{YE}_{2}\right.$ and $\left.\mathrm{YE}_{3}\right)$ at different time periods $\left(1^{\text {st }}\right.$ day, $10^{\text {th }}$ day and $20^{\text {th }}$ day) where $1^{\text {st }}$ day yoghurt were taken as control. Yoghurt $\left(\mathrm{YA}_{1} / \mathrm{YE}_{1}\right.$, $\mathrm{YA}_{2} / \mathrm{YE}_{2}$ and $\mathrm{YA}_{3} / \mathrm{YE}_{3}$ ) formulations were fortified with $0,0.05,0.10,0.15 \%(\mathrm{~W} / \mathrm{V})$ with goji berry polyphenolic aqueous/ethanolic fruit extract

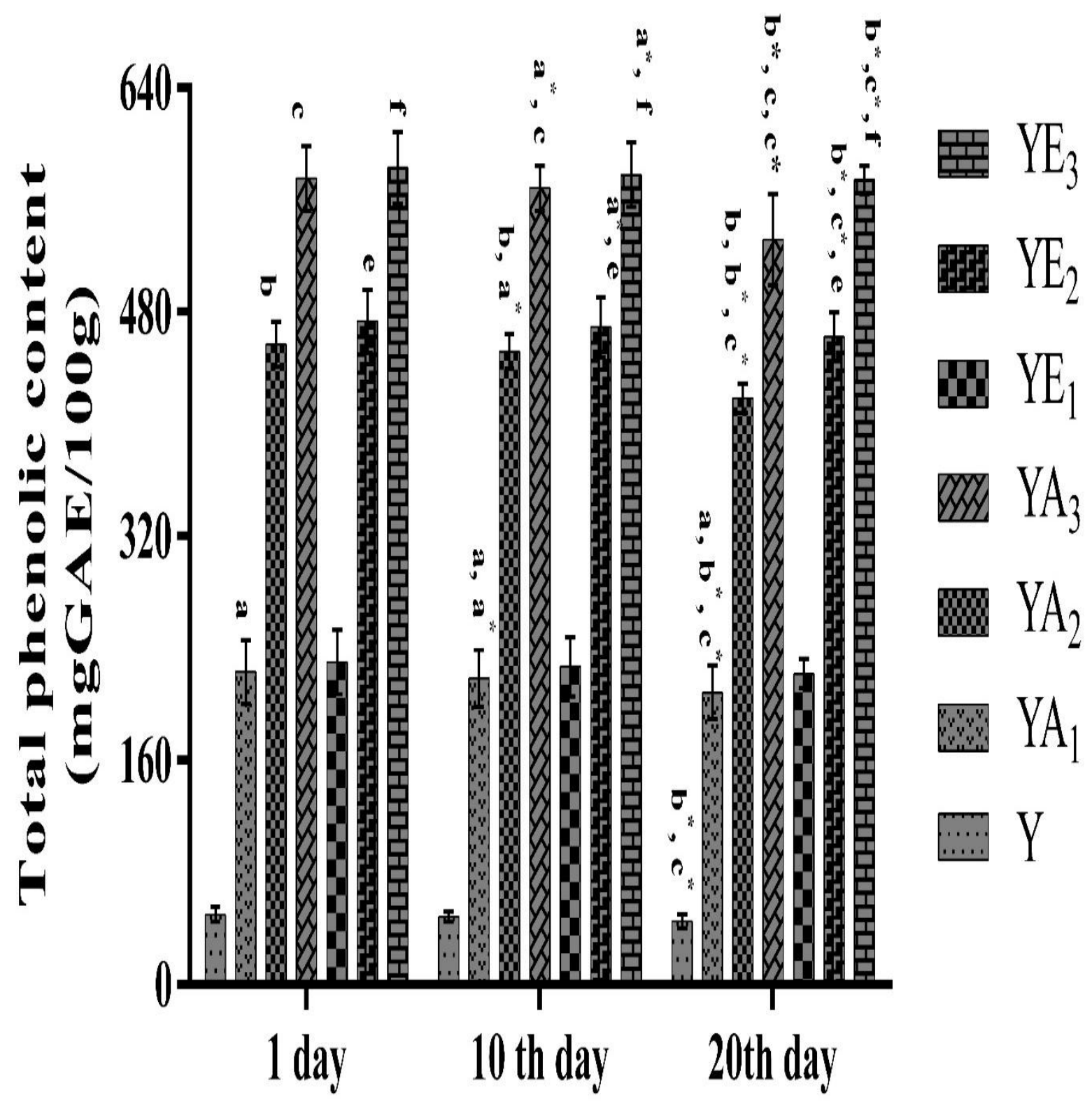


Fig.2 Antioxidant activity of yoghurt fortified with goji berry polyphenolic aqueous/ethanolic extract and vitamin $D$. Values are expressed in mean $\pm S D(n=3)(p \leq 0.05)$. a, b, c, d, e, and $f$ represent significant differences between $\mathrm{Y} \times \mathrm{YA}_{1}, \mathrm{Y} \times \mathrm{YA}_{2}, \mathrm{Y} \times \mathrm{YA}_{3}, \mathrm{Y} \times \mathrm{YE}_{1}, \mathrm{Y} \times \mathrm{YE}_{2}$, and $\mathrm{Y} \times \mathrm{YE}_{3}$ within the $1^{\text {st }}$ day, $10^{\text {th }}$ day and $20^{\text {th }}$ day yoghurt formulations where $\mathrm{Y}$ formulation is considered as control with each group $\left(1^{\text {st }}\right.$ day, $10^{\text {th }}$ day and $20^{\text {th }}$ day $)$. Further $\mathrm{a}^{*}, \mathrm{~b}^{*}$ and $\mathrm{c}^{*}$ represent significance difference between $1^{\text {st }}$ day x $10^{\text {th }}$ day, $1^{\text {st }}$ day $\times 20^{\text {th }}$ and $10^{\text {th }}$ day $\times 20^{\text {th }}$ day within individual samples $\left(\mathrm{Y}, \mathrm{YA}_{1}, \mathrm{YA}_{2}, \mathrm{YA}_{3}, \mathrm{YE}_{1}, \mathrm{YE}_{2}\right.$ and $\left.\mathrm{YE}_{3}\right)$ at different time periods $\left(1^{\text {st }}\right.$ day, $10^{\text {th }}$ day and $20^{\text {th }}$ day) where $1^{\text {st }}$ day yoghurt were taken as control. Yoghurt $\left(\mathrm{YA}_{1} / \mathrm{YE}_{1}\right.$, $\mathrm{YA}_{2} / \mathrm{YE}_{2}$ and $\mathrm{YA}_{3} / \mathrm{YE}_{3}$ ) formulations were fortified with $0,0.05,0.10,0.15 \%(\mathrm{~W} / \mathrm{V})$ with goji berry polyphenolic aqueous/ethanolic fruit extract

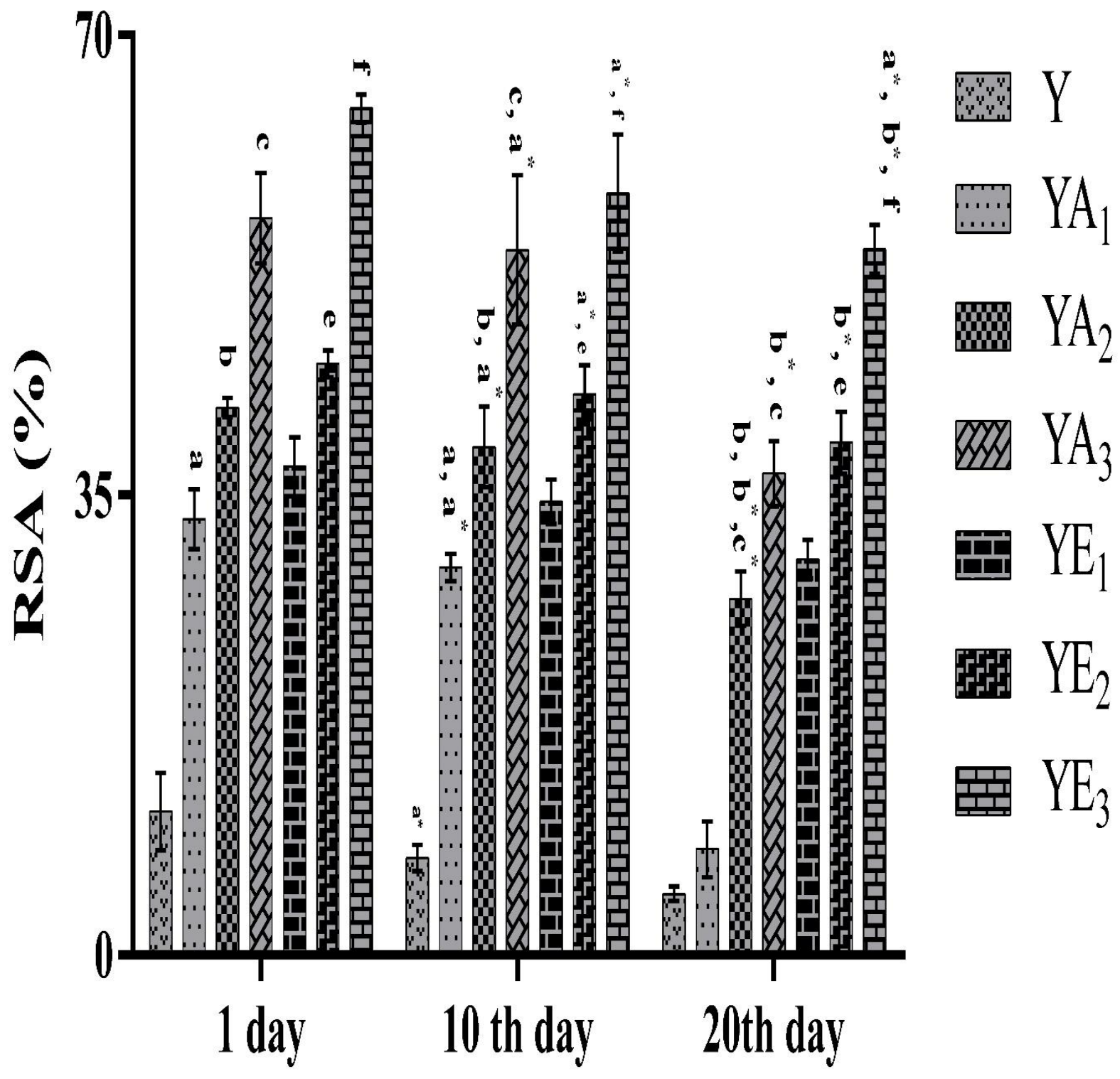


Fig.3 pH of yoghurt fortified with goji berry polyphenolic aqueous/ethanolic extract and vitamin D. Values are expressed in mean $\pm \mathrm{SD}(\mathrm{n}=3)(\mathrm{p} \leq 0.05)$. a, b, c, d, e, and f represent significant differences between $\mathrm{Y} \times \mathrm{YA}_{1}, \mathrm{Y} \times \mathrm{YA}_{2}, \mathrm{Y} \times \mathrm{YA}_{3}, \mathrm{Y} \times \mathrm{YE}_{1}, \mathrm{Y} \times \mathrm{YE}_{2}$, and $\mathrm{Y} \times \mathrm{YE}_{3}$ within the $1^{\text {st }}$ day, $10^{\text {th }}$ day and $20^{\text {th }}$ day yoghurt formulations where $\mathrm{Y}$ formulation is considered as control with each group $\left(1^{\text {st }}\right.$ day, $10^{\text {th }}$ day and $20^{\text {th }}$ day). Further $a^{*}, b^{*}$ and $c^{*}$ represent significance difference between $1^{\text {st }}$ day $\times 10^{\text {th }}$ day, $1^{\text {st }}$ day $\times 20^{\text {th }}$ and $10^{\text {th }}$ day $\times 20^{\text {th }}$ day within individual samples $\left(\mathrm{Y}, \mathrm{YA}_{1}, \mathrm{YA}_{2}, \mathrm{YA}_{3}, \mathrm{YE}_{1}, \mathrm{YE}_{2}\right.$ and $\left.\mathrm{YE}_{3}\right)$ at different time periods $\left(1^{\text {st }}\right.$ day, $10^{\text {th }}$ day and $20^{\text {th }}$ day) where $1^{\text {st }}$ day yoghurt were taken as control. Yoghurt $\left(\mathrm{YA}_{1} / \mathrm{YE}_{1}, \mathrm{YA}_{2} / \mathrm{YE}_{2}\right.$ and $\left.\mathrm{YA}_{3} / \mathrm{YE}_{3}\right)$ formulations were fortified with $0,0.05,0.10,0.15 \%(\mathrm{~W} / \mathrm{V})$ with goji berry polyphenolic aqueous/ethanolic fruit extract

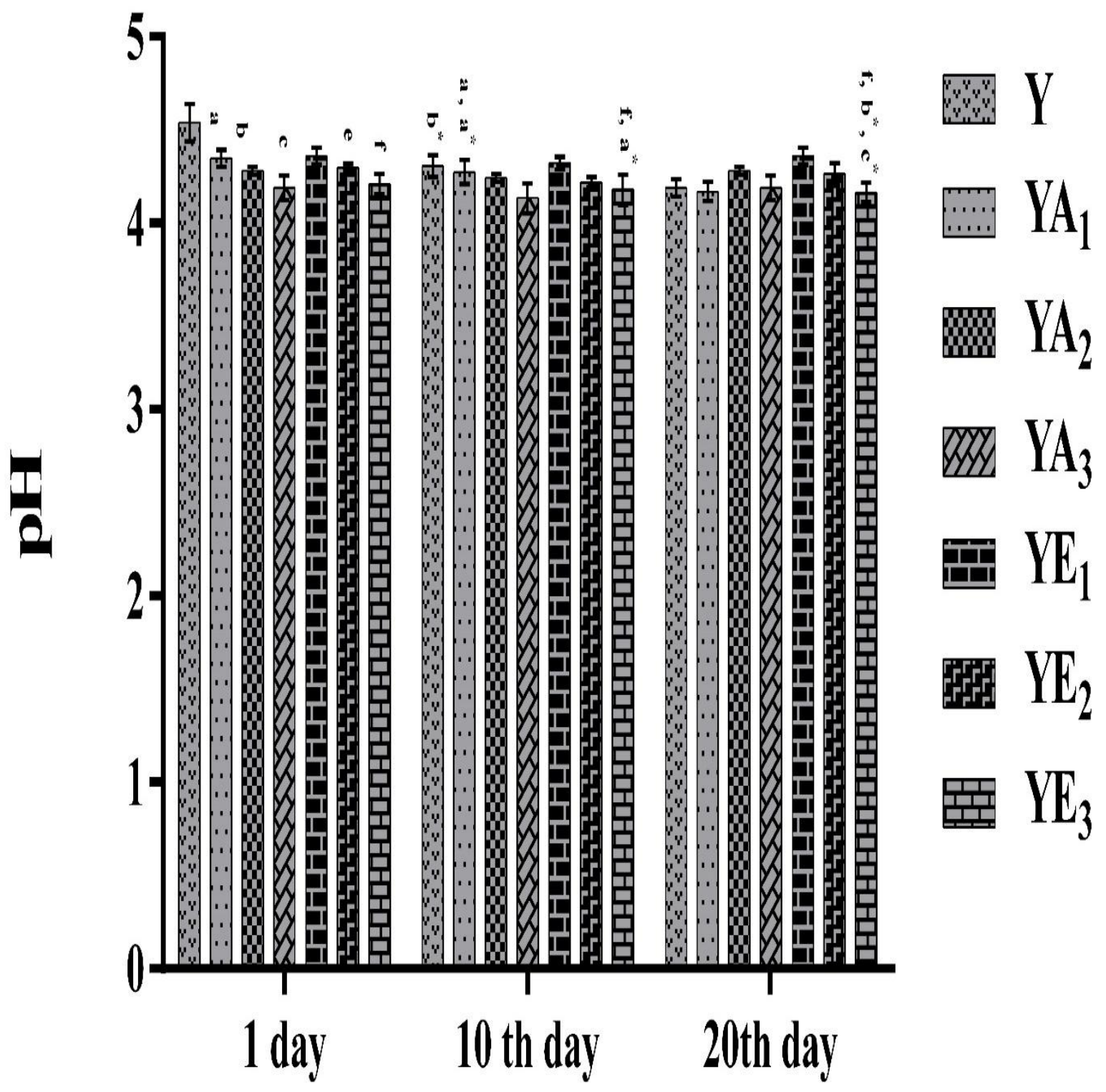


Fig.4 Vitamin D retention in yoghurt fortified with gojiberry polyphenolic aqueous/ethanolic extract and vitamin D. Values are expressed in mean $\pm \mathrm{SD}(\mathrm{n}=3)(\mathrm{p} \leq 0.05)$. a, b, c, d, e, and $\mathrm{f}$ represent significant differences between $\mathrm{Y} \times \mathrm{YA}_{1}, \mathrm{Y} \times \mathrm{YA}_{2}, \mathrm{Y} \times \mathrm{YA}_{3}, \mathrm{Y} \times \mathrm{YE}_{1}, \mathrm{Y} \times \mathrm{YE}_{2}$, and $\mathrm{Y} \times \mathrm{YE}_{3}$ within the $1^{\text {st }}$ day, $10^{\text {th }}$ day and $20^{\text {th }}$ day yoghurt formulations where $\mathrm{Y}$ sample is considered as control with each group $\left(1^{\text {st }}\right.$ day, $10^{\text {th }}$ day and $20^{\text {th }}$ day). Further $\mathrm{a}^{*}, \mathrm{~b}^{*}$ and $\mathrm{c}^{*}$ represent significance difference between $1^{\text {st }}$ day x $10^{\text {th }}$ day, $1^{\text {st }}$ day $\times 20^{\text {th }}$ and $10^{\text {th }}$ day $\times 20^{\text {th }}$ day within individual samples $\left(\mathrm{Y}, \mathrm{YA}_{1}, \mathrm{YA}_{2}, \mathrm{YA}_{3}, \mathrm{YE}_{1}, \mathrm{YE}_{2}\right.$ and $\left.\mathrm{YE}_{3}\right)$ at different time periods $\left(1^{\text {st }}\right.$ day, $10^{\text {th }}$ day and $20^{\text {th }}$ day) where $1^{\text {st }}$ day yoghurt samples were taken as control. Where $\mathrm{YA}_{1} / \mathrm{YE}_{1}, \mathrm{YA}_{2} / \mathrm{YE}_{2}$ and $\mathrm{YA}_{3} / \mathrm{YE}_{3} /$ formulations were fortified with $0,0.05,0.10,0.15 \%$ (W/V) with goji berry polyphenolic aqueous/ethanolic fruit extract

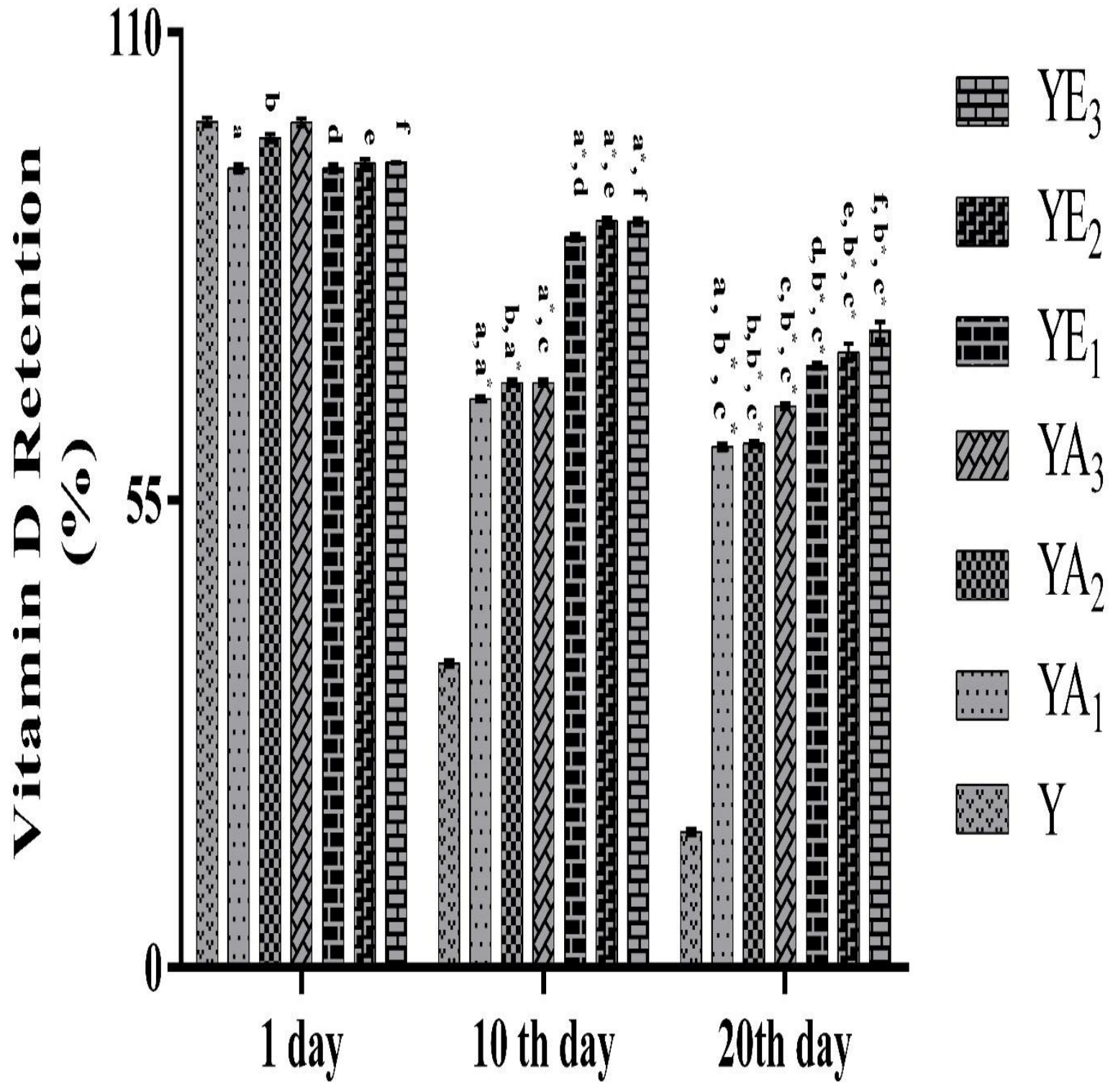


Fig.5 Overall consumer acceptability of yoghurt fortified with goji berry polyphenolic aqueous/ethanolic extract and vitamin $\mathrm{D}$. Values are expressed in mean $\pm \mathrm{SD}(\mathrm{n}=3)(\mathrm{p} \leq 0.05)$. a, $\mathrm{b}, \mathrm{c}, \mathrm{d}$, e, and $\mathrm{f}$ represent significant differences between $\mathrm{Y} \times \mathrm{YA}_{1}, \mathrm{Y} \times \mathrm{YA}_{2}, \mathrm{Y} \times \mathrm{YA}_{3}, \mathrm{Y} \times \mathrm{YE}_{1}$, $\mathrm{Y} \times \mathrm{YE}_{2}$, and $\mathrm{Y} \times \mathrm{YE}_{3}$ within the $1^{\text {st }}$ day, $10^{\text {th }}$ day and $20^{\text {th }}$ day yoghurt formulations where $\mathrm{Y}$ formulation is considered as control with each group $\left(1^{\text {st }}\right.$ day, $10^{\text {th }}$ day and $20^{\text {th }}$ day). Further ${ }^{*}$, $\mathrm{b}^{*}$ and $\mathrm{c}^{*}$ represent significance difference between $1^{\text {st }}$ day x $10^{\text {th }}$ day, $1^{\text {st }}$ day x $20^{\text {th }}$ and $10^{\text {th }}$ day $\mathrm{x}$ $20^{\text {th }}$ day within individual samples $\left(\mathrm{Y}, \mathrm{YA}_{1}, \mathrm{YA}_{2}, \mathrm{YA}_{3}, \mathrm{YE}_{1}, \mathrm{YE}_{2}\right.$ and $\left.\mathrm{YE}_{3}\right)$ at different time periods $\left(1^{\text {st }}\right.$ day, $10^{\text {th }}$ day and $20^{\text {th }}$ day) where $1^{\text {st }}$ day yoghurt were taken as control. Yoghurt $\left(\mathrm{YA}_{1} / \mathrm{YE}_{1}, \mathrm{YA}_{2} / \mathrm{YE}_{2}\right.$ and $\left.\mathrm{YA}_{3} / \mathrm{YE}_{3}\right)$ formulations were fortified with $0,0.05,0.10,0.15 \%$ (W/V) with goji berry polyphenolic aqueous/ethanolic fruit extract

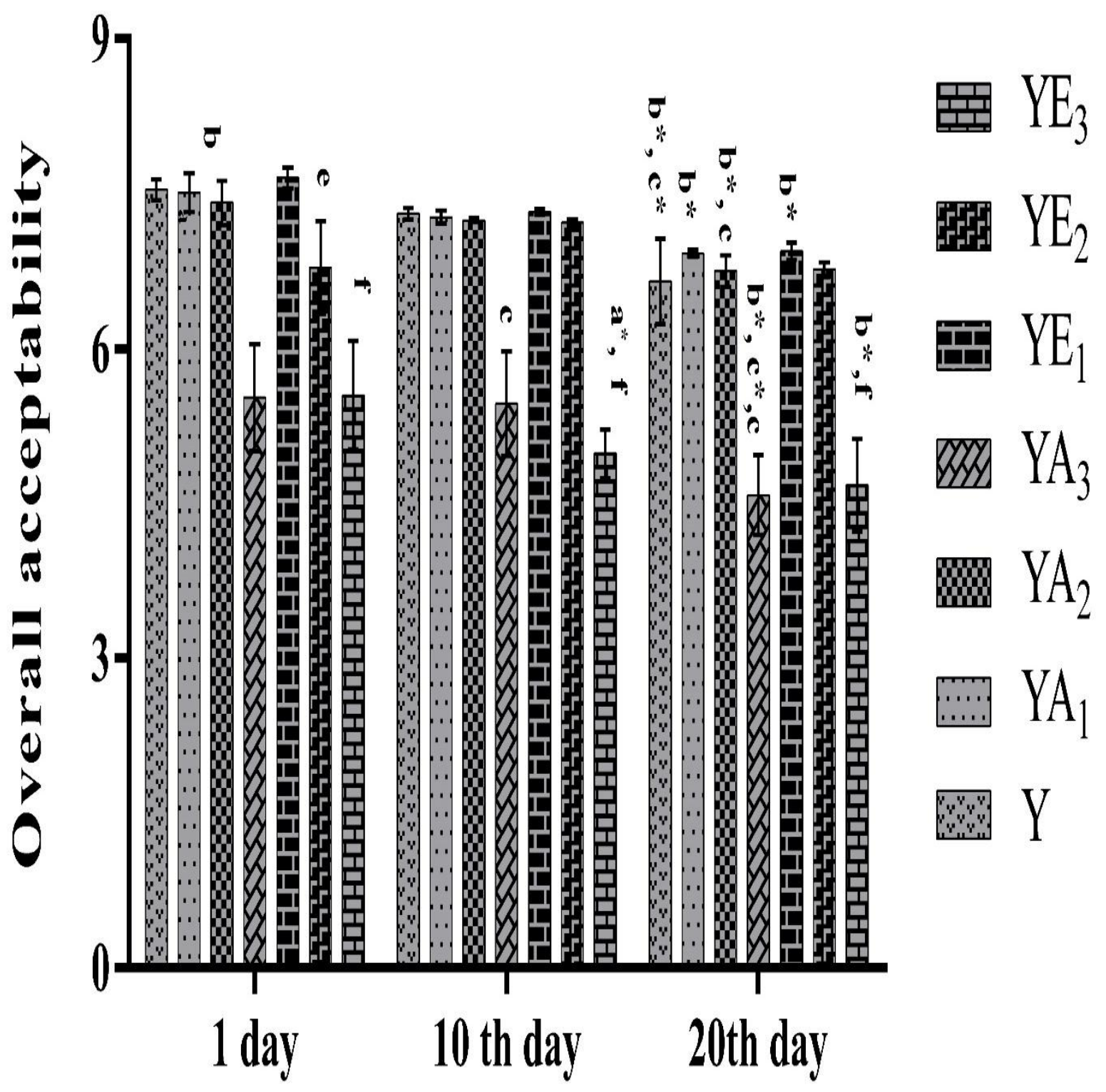


Yoghurt fortification

\begin{tabular}{|c|c|c|c|c|}
\hline $\begin{array}{c}\text { Formulation } \\
\text { code }\end{array}$ & Toned milk & $\begin{array}{c}\text { Aqueous extract } \\
(\mathbf{g} / \mathbf{1 0 0} \mathbf{m})\end{array}$ & $\begin{array}{c}\text { Ethanolic extract } \\
(\mathbf{g} / \mathbf{1 0 0} \mathbf{m L})\end{array}$ & $\begin{array}{c}\text { Vitamin D } \\
\boldsymbol{\mu g} / \mathbf{I U} / \mathbf{1 0 0} \mathbf{m L}\end{array}$ \\
\hline $\mathrm{Y}$ & 100 & 0 & 0 & $12.5 / 500$ \\
\hline $\mathrm{YA}_{1}$ & 100 & 0.05 & 0 & $12.5 / 500$ \\
\hline $\mathrm{YA}_{1}$ & 100 & 0.10 & 0 & $12.5 / 500$ \\
\hline $\mathrm{YA}_{3}$ & 100 & 0.15 & 0 & $12.5 / 500$ \\
\hline $\mathrm{YE}_{1}$ & 100 & 0 & 0.05 & $12.5 / 500$ \\
\hline $\mathrm{YE}_{2}$ & 100 & 0 & 0.10 & $12.5 / 500$ \\
\hline $\mathrm{YE}_{3}$ & 100 & 0 & 0.15 & $12.5 / 500$ \\
\hline
\end{tabular}

Vitamin D retention in polyphenolic extract supplemented yoghurt

Vitamin D was quantified in goji berry supplemented aqueous and ethanolic extract yoghurt and displayed in figure 4. The extraction efficiency of vitamin D from different yoghurt formulation lied between 90-95\%. The results revealed that as the concentration of polyphenolic extract increases the vitamin D retention enhanced significantly for both aqueous and ethanolic extract. But yoghurt supplemented with ethanolic goji berry extract has greater vitamin $\mathrm{D}$ retention than that of aqueous extract. This can be correlated with high antioxidant activity and high total phenolic content in ethanolic extract than that of aqueous extract. Vitamin $\mathrm{D}$ is prone to oxidation which can be inhibited by addition of antioxidant. Figure 4 clearly shows that as the antioxidant activity decreases during storage vitamin $\mathrm{D}$ degradation also increases. The lowest vitamin $\mathrm{D}$ retention during storage of 20 days was recorded in control (Y) which varied from $99.55 \%$ on $1^{\text {st }}$ day to $15.97 \%$ on $20^{\text {th }}$ day) while the highest retention was registered in $\mathrm{YE}_{3}$ formulation which changed from $94.7 \%$ on $1^{\text {st }}$ day to $74.9 \% 20^{\text {th }}$ day.

\section{Sensory evaluation of soy blended yoghurt}

Sensory evaluation is a key to potential consumer preferences. Sensory characteristics of goji berry extract supplement and vitamin
D fortified yoghurt formulation are presented based on the mean score of and over all acceptability (mean of colour, flavour, body texture) of yoghurt prepared (Figure 5). It was observed that mean score for overall acceptability was in the range of 7.51-5.52 (Y and $\mathrm{YA}_{3}$ within $1^{\text {st }}$ day formulations). The highest acceptability was reported for control yoghurt while it was least for $\mathrm{YA}_{3}$. Figure 5 also shows that the overall acceptability was decreased during the storage period of 20 days. Similar conclusion was made by several other researchers when they supplemented yoghurt with different types polyphenolic extracts (Cossu et al., 2009 El-Said et al., 2014; Karaaslan et al., 2011). It is observable that the consumer acceptability of $\mathrm{YE}_{2}$ formulation was next control formulation in overall acceptability. This indicates that yoghurt supplemented with $0.1 \%$ (W/V) ethanolic extract is the most suitable formulation for delivery of vitamin $\mathrm{D}$ as well as natural antioxidant without affecting the consumer palatability.

In conclusion, the present study validated that goji aqueous and ethanolic extracts can be effectively employed for production of polyphenol fortified yoghurt with high antioxidant properties. Ethanolic extract has displayed higher content of polyphenols and antioxidant activity followed than that of aqueous extract extracts, these extracts definitely affected the phenolic content in yoghurt during 20 days of refrigerated 
storage. HPLC analysis revealed the absence of phenolic extract in yoghurts, vitamin D was susceptible to degradation. However, all yoghurts formulation showed high antioxidant activity compared to control yoghurt formulation (Y) during 20 days of storage. In addition, yoghurt formulations supplemented with ethanolic extract showed higher antioxidant activity among the other formulations. Further study on the consumer sensory evaluation reveals that as the concentration of aqueous/ethanolic goji berry fruit extract the overall consumer acceptability decreased. This study clearly suggests that yoghurt supplemented with $0.10 \%$ (W/V) ethanolic goji berry extract could be the most feasible option to ensure high antioxidant activity as well high vitamin $D$ retention without affecting the acceptability and palatability of yoghurt.

\section{References}

AOAC. 979.24. Official Methods of Analysis, 15th ed.; Association ofOfficial Analytical Chemists: Arlington, VA, 1990. Official Methods of Analysis.

Benchennouf, A., Grigorakis, S., Loupassaki, S., Kokkalou, E. 2017. Phytochemical analysis and antioxidant activity of Lycium barbarum (Goji) cultivated in Greece. Pharmaceutical biology. 55, 596-602.

Bulambaeva, A., Vlahova-Vangelova, D., Dragoev, S., Balev, D., Uzakov, Y. 2014. Development of new functional cooked sausages by addition of goji berry and pumpkin powder. Am. J. Food Technol. 9, 180-189.

Chen, L., Xin, X., Yuan, Q., Su, D., Liu, W. 2014. Phytochemical properties and antioxidant capacities of various colored berries. Journal of the Science of Food and Agriculture. 94, 180-188.

Cossu, M., Juliano, C.C.A., Pisu, R., Alamanni, M.C.P. 2009. Effects of enrichment with polyphenolic extracts from Sardinian plants on physicochemical, antioxidant and microbiological properties of yogurt. Italian Journal of Food Science. 21, 447-459.

Dimartino, G. 2007. Convenient analysis of vitamin $\mathrm{D}$ in cheese and other food matrixes by liquid chromatography/mass spectrometry. Journal of AOAC International. 90, 1340-1345.

Donno, D., Beccaro, G., Mellano, M., Cerutti, A., Bounous, G. 2015. Goji berry fruit (Lycium spp.): antioxidant compound fingerprint and bioactivity evaluation. Journal of functional foods. 18, 1070 1085.

Ducruet, J., Rébénaque, P., Diserens, S., Kosińska-Cagnazzo, A., Héritier, I., Andlauer, W. 2017. Amber ale beer enriched with goji berries-The effect on bioactive compound content and sensorial properties. Food Chemistry. 226, 109-118.

El-Said, M.M., Haggag, H., El-Din, H.M.F., Gad, A., Farahat, A.M. 2014. Antioxidant activities and physical properties of stirred yoghurt fortified with pomegranate peel extracts. Annals of Agricultural Sciences. 59, 207-212.

Fathi, M., Varshosaz, J. 2013. Novel hesperetin loaded nanocarriers for food fortification: Production and characterization. Journal of Functional Foods. 5, 1382-1391.

Grady, L., Thakker, K. 1980. Stability of solid drugs: degradation of ergocalciferol (vitamin D2) and cholecalciferol (vitamin D3) at high humidities and elevated temperatures. Journal of pharmaceutical sciences. 69, 10991102.

Grant, J., Ryland, D., Isaak, C.K., Prashar, S., Siow, Y.L., Taylor, C.G., Aliani, M. 2017. Effect of Vitamin D3 
Fortification and Saskatoon Berry Syrup Addition on the Flavor Profile, Acceptability, and Antioxidant Properties of Rooibos Tea (Aspalathus linearis). Journal of Food Science. 82, 807-817.

Heurtault, B., Saulnier, P., Pech, B., VenierJulienne, M.-C., Proust, J.-E., PhanTan-Luu, R., Benoit, J.-P. 2003. The influence of lipid nanocapsule composition on their size distribution. European Journal of Pharmaceutical Sciences. 18, 55-61.

Karaaslan, M., Ozden, M., Vardin, H., Turkoglu, H. 2011. Phenolic fortification of yogurt using grape and callus extracts. LWT - Food Science and Technology. 44, 1065-1072.

Kiani, A., Fathi, M., Ghasemi, S.M. 2017. Production of novel vitamin D3 loaded lipid nanocapsules for milk fortification. International Journal of Food Properties. 1-11.

LI, T.L., MIN, D.B. 1998. Stability and photochemistry of vitamin D2 in model system. Journal of Food science. 63, 413-417.

Morais Ferreira, J.M., Azevedo, B.M., Luccas, V., Bolini, H.M.A. 2017. Sensory Profile and Consumer Acceptability of Prebiotic White Chocolate with Sucrose Substitutes and the Addition of Goji Berry (Lycium barbarum). Journal of Food Science. $82,818-824$.

Navarro, P., Nicolas, T.S., Gabaldon, J.A., Mercader- Ros, M.T., Calín- Sánchez, Á., Carbonell- Barrachina, Á.A., Pérez- López, A.J. 2011. Effects of cyclodextrin type on vitamin C, antioxidant activity, and sensory attributes of a mandarin juice enriched with pomegranate and goji berries. Journal of food science. 76.

Pastore, R.J., Dunnett, R.V., Webster, G.K. 1997. Dimethyl sulfoxide extraction method for the liquid chromatographic analysis of microencapsulated vitamin D3. Journal of agricultural and food chemistry. 45, 1784-1786.

ROTAR, A.M., Semeniuc, C., Bunghez, F., Jimborean, M., Pop, C. 2014. Effect of Different Storage Period on Lactic Acid Bacterias from Goji Yogurt and Goji Yogurt with Honey. Bulletin UASVM Food Science and Technology. 71, 7576.

Rotar, A.M., Vodnar, D.C., Bunghez, F., Catunescu, G.M., Carmen, R.P., Jimborean, M., Semeniuc, C.A. 2015. Effect of goji berries and honey on lactic acid bacteria viability and shelf life stability of yoghurt. Notulae Botanicae Horti Agrobotanici ClujNapoca. 43, 196.

Roy, A., Lakshmy, R., Tarik, M., Tandon, N., Reddy, K.S., Prabhakaran, D. 2015. Independent association of severe vitamin $\mathrm{D}$ deficiency as a risk of acute myocardial infarction in Indians. Indian heart journal. 67, 27-32.

Singh, R., Kumar, R., Venkateshappa, R., Mann, B., Tomar, S.K. 2013. Studies on physicochemical and antioxidant properties of strawberry polyphenol extract-fortified stirred dahi. International Journal of Dairy Technology. 66, 103-108.

Tangpricha, V., Koutkia, P., Rieke, S.M., Chen, T.C., Perez, A.A., Holick, M.F. 2003. Fortification of orange juice with vitamin D: a novel approach for enhancing vitamin D nutritional health. The American journal of clinical nutrition. 77, 1478-1483.

Tunde-Akintunde, T., Souley, A. 2009. Effect of processing methods on quality of soymilk. Pakistan journal of Nutrition. $8,1156-1158$.

Vulić, J.J., Čanadanović-Brunet, J.M., Cetković, G.S., Djilas, S.M., Tumbas Šaponjac, V.T., Stajčić, S.S. 2016. 
Bioactive Compounds and Antioxidant Properties of Goji fruits (Lycium barbarum L.) Cultivated in Serbia. Journal of the American College of Nutrition. 35, 692-698.

Wagner, D., Rousseau, D.r., Sidhom, G., Pouliot, M., Audet, P., Vieth, R. 2008. Vitamin D3 fortification, quantification, and long-term stability in Cheddar and low-fat cheeses. Journal of agricultural and food chemistry. 56, 7964-7969.

Wayse, V., Yousafzai, A., Mogale, K., Filteau, S. 2004. Association of subclinical vitamin D deficiency with severe acute lower respiratory infection in Indian children under $5 \mathrm{y}$. European journal of clinical nutrition. 58, 563567.
Yang, R.-f., Zhao, C., Chen, X., Chan, S.-w., Wu, J.-y. 2015. Chemical properties and bioactivities of Goji (Lycium barbarum) polysaccharides extracted by different methods. Journal of Functional Foods. 17, 903-909.

Yang, Y. 2016. Utilization of a By-Product from Goji Berry Beverage as a ValueAdded Ingredient in Chinese Steamed Bread.

Zhang, J. 2013. Antioxidant properties of goji berry. Wayne State University.

Zhang, Q., Chen, W., Zhao, J., Xi, W. 2016. Functional constituents and antioxidant activities of eight Chinese native goji genotypes. Food Chemistry. 200, 230236.

\section{How to cite this article:}

Vaibhav Kumar Maurya and Manjeet Aggarwal. 2017. Impact of Aqueous/Ethanolic Goji Berry (Lycium barbarum) Fruit Extract Supplementation on Vitamin D Stability in Yoghurt. Int.J.Curr.Microbiol.App.Sci. 6 (8): 2016-2029. doi: https://doi.org/10.20546/ijcmas.2017.608.240 